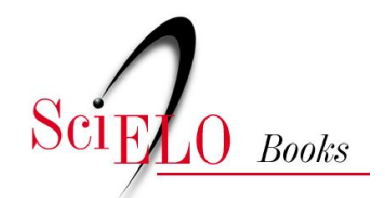

\title{
O exercício da dor de amar em Cartas portuguesas de Mariana Alcoforado
}

\author{
Marcelo Medeiros da Silva
}

\section{SciELO Books / SciELO Livros / SciELO Libros}

SILVA, MM. O exercício da dor de amar em Cartas Portuguesas de Marina Alcoforado. In:

MEDEIROS, A., org. Travessias pela literatura portuguesa: estudos críticos de Saramago a Vieira [online]. Campina Grande: EDUEPB, 2013, pp. 175-205. ISBN 9788578792794. Available from SciELO Books $<\underline{\text { http://books.scielo.org }>}$

\section{(c) $\frac{1}{\mathrm{BV}}(2)$ (2)}

All the contents of this work, except where otherwise noted, is licensed under a Creative Commons Attribution-Non Commercial-ShareAlike 3.0 Unported.

Todo o conteúdo deste trabalho, exceto quando houver ressalva, é publicado sob a licença Creative Commons Atribuição Uso Não Comercial - Partilha nos Mesmos Termos 3.0 Não adaptada.

Todo el contenido de esta obra, excepto donde se indique lo contrario, está bajo licencia de la licencia Creative Commons Reconocimento-NoComercial-CompartirIgual 3.0 Unported. 


\title{
O exercício da dor de amar em Cartas portuguesas de Mariana Alcoforado
}

\author{
Marcelo Medeiros da Silva
}

[...] tu serves apenas de motivação, de início, de peça envolvente em que te arrasto neste meu muito maior prazer em me sentir apaixonada que em amar-te. Neste meu muito maior prazer em dizer que te amo do que na verdade em querer-te.

[...]

E assim sofro, aparentemente porque te amo, mas antes porque perco o motivo de alimento da minha paixão, a quem talvez bem mais queira do que a ti.

[...]

Assim te procuro, te uso, te escrevo; porém, as palavras não são elos, nem pontes, nem laços a desatar na solidão das salas.

Novas cartas portuguesas. 
Cartas Portuguesas é exemplo modelar da epistolografia literária em prosa, na esteira de outros do gênero, como Pâmela (1740) e Clarissa (1748), de Samuel Richardeson; Cartas Persas (1721), de Montesquieu; A nova Heloisa (1761), de Rousseau; As ligações perigosas (1782), de Choderlos de Laclos ou Os sofrimentos do jovem Wether (1774), de Goethe. Apesar das dúvidas levantadas com relação à autoria, ao número total de cartas, à participação de outrem na sua publicação, os créditos da publicação de Cartas Portuguesas foram atribuídos a Mariana Alcoforado, que nasceu em 1640, na cidade de Beja. Logo cedo, aos doze anos, ela ingressou no Convento de Nossa Senhora da Conceição e veio a falecer em 28 de julho de 1723.

Publicadas, primeiramente, em francês, em 1669, em Paris, com o título de Lettres Portugaises traduites en français, e somente vertidas para o português, em 1810, por Filinto Elísio, as cinco cartas de amor escritas pela freira de Beja têm despertado o interesse de vários leitores e servido de modelo para a expressão de dramas amorosos semelhantes aos expressos pela missivista. As cartas eram dirigidas a um oficial francês que, em 1663, estava de passagem por Portugal e atendia pelo nome de Noël-Bouton de Chamilly, Conde de Saint-Léger. Precisando retornar ao seu país de origem, ele deixou de lado aquela por quem havia se enamorado e que, diante do silêncio do amado, fez das cartas o registro de tão intenso amor e locus de enunciação de um sujeito feminino que, apesar do enclausuramento, ousou falar do (sofrer de) amor.

Cartas Portuguesas, de Sóror Mariana Alcoforado, é um romance epistolar, gênero que surge entre o final do século 
XVII e albores do século XVIII, desfrutando de notória popularidade, notadamente na França e na Inglaterra, países em que o acentuado desenvolvimento dos correios propiciou o surgimento desse gênero narrativo. De acordo com Paixão (1987), dentre as singularidades do romance epistolar, para haver a sustentação dos elementos que compõem a diegese narrativa desse gênero, as cartas que o enformam devem estar, de preferência, organizadas em série e o autor deve emprestar à sua narrativa credibilidade, apresentando elementos que a façam ser tomada como real. Estruturado geralmente em torno de um narrador autodiegético, no caso a freira de Beja, tomando-se, aqui, a obra em comento, o romance epistolar é marcado pela narração de acontecimentos, pensamentos e/ou sentimentos vividos pelo próprio narrador que se apresenta como personagem principal da história:

Parece-me que faço a maior afronta do mundo aos sentimentos do meu coração quando procuro dar-tos a conhecer escrevendo-os.

[...] não sei porque te escrevo. Bem vejo que nada mais terás por mim do que compaixão - e, essa, não a quero!

Enfureço-me contra mim própria quando penso em tudo quanto te sacrifiquei: perdi a minha reputação, expus-me ao furor dos meus parentes, à severidade das leis deste país contra as religiosas e à tua ingratidão, que me parece a maior de todas as desgraças (ALCOFORADO, 1974, p. 27;45). 
Em virtude da presença de um narrador autodiegético, Cartas Portuguesas apresenta uma focalização interna e restritiva. De acordo com Aguiar e Silva (1979), por focalização interna, muito comum em romances de focalização homodiegética, particularmente nos de focalização autodiegética, entendam-se a descrição e a análise, por parte do narrador, daquilo que se passa no interior das personagens. No caso de Mariana, as angústias e os sofrimentos advindos da ausência, do abandono e da indiferença de Noël-Bouton de Chamilly, narratário intradiegético, a quem se refere e para quem escreve suas cartas:

Mas, antes de te deixares dominar por uma grande paixão, pensa bem no excesso das minhas dores, na incerteza dos meus projectos, na diversidade dos meus arroubos, na extravagância das minhas cartas, nas minhas confianças, nos meus desesperos, no meu ciúme! Olha que vais ser um desgraçado! Conjuro-te a que aproveites alguma coisa do estado em que me encontro e que ao menos o que sofro por ti seja de alguma utilidade! (ALCOFORADO, 1974, p. 71).

Já por focalização restritiva, devemos entender aquele tipo de focalização que "problematiza as personagens e os eventos diegéticos" e, consequentemente, obriga "o leitor a um esforço, árduo muitas vezes, para apreender o significado da narrativa", uma vez que o narrador "não dilucida tudo miudamente, nem estabelece autoritariamente uma interpretação: há fatos susceptíveis de várias interpretações, há dúvidas e equívocos que permanecem, há silêncios 
que ninguém revela..." (AGUIAR E SILVA, 1979, p. 335). Ou seja, como narradora, isto é, como a instância produtora do discurso narrativo, Mariana é quem manipula os eventos da diegese narrativa, de maneira que as suas palavras, de certa forma, devem ser postas sob suspeita, já que ela assume-se como centro da cena enunciativa, não dando espaço para que o seu destinatário se pronuncie. Por esse aspecto, Cartas Portuguesas é, no dizer de Valentin (2006), um romance epistolar solista cujo signatário (Mariana) dirige-se a um único destinatário (Chamilly).

Como "a relação do narrador com o universo diegético e com o narratário se institui em níveis diversos e apresenta, portanto, conteúdos e significados distintos", a escolha de uma focalização autodiegética é um dos aspectos singulares da estrutura narrativa de Cartas Portuguesas, uma vez que, por meio desse tipo de focalização, é possível realizar "o devassamento da interioridade da personagem nuclear do romance, uma vez que é essa mesma personagem que narra os acontecimentos e que a si própria se desnuda", trazendo à tona as suas "mais subtis emoções, os [seus] pensamentos mais secretos, o ritmo da vida interior" (AGUIAR E SILVA, 1979, p. 327). Enfim, a utilização de uma focalização autodiegética, como um recurso narrativo, permite ao narratário extradiegético de Cartas Portuguesas, ao contrário do narratário intradiegético da referida obra, ser posto diante daquilo que constitui a história da intimidade da signatária das cartas, daquilo que foi miudamente analisado e confessado por ela mesma que viveu os eventos que sustentam a diegese narrativa e são, portanto, responsáveis pelo desenvolvimento da ação romanesca. Essa ação se centra na narração da irrupção do desejo de uma freira 
por um oficial francês e, por conseguinte, da apresentação de um mundo interior devassado por esse amor e marcado pela ausência de lógica:

Perdoa-me! Eu não te culpo de nada! Não estou em condições de pensar em minha vingança e só acuso a dureza da minha sorte. Parece-me que, ao separar-nos, ela nos fez ver todo o mal que tínhamos a temer: os nossos corações não os podia ela separar! O amor, mais poderoso do que ela, uniu-os para toda a vida.

Se tens interesse pela minha, escreve-me muitas vezes. Bem mereço que te dês ao cuidado de me informar sobre o estado do teu coração e da tua vida. Peço-te, sobretudo, que me venhas ver! Adeus! Não posso largar este papel! Ele cairá nas tuas mãos: bem quisera ter eu a mesma sorte! Ai de mim! Louca que sou! Bem me dou conta de que isso não é possível! (ALCOFORADO, 1974, p. 19-21).

O turbilhão de emoções desenfreadas que dão sustentação a um mundo interior marcado pela presença de incoerências entre os fatos havidos e os desejos expressos pela narradora-personagem irão contribuir, segundo Valentin (2006), para a instauração de um tempo narrativo pautado muito mais nas idas e vindas da memória do que, propriamente, na ordenação cronológica dos fatos. Como podemos perceber no excerto abaixo, o marcador temporal "dentro de poucos dias", apesar de apontar para um tempo futuro, fá-lo em relação a um tempo passado, tomando como ponto de convergência um mesmo evento - o momento exato em 
que a narradora encontrou-se apaixonada por aquele por quem, no tempo presente da diegese, ela sofre:

Dentro de poucos dias, vai fazer um ano que me abandonei totalmente a ti, sem quaisquer reservas. A tua paixão parecia-me bem ardente e sincera, e nunca pensei que os meus favores te tivessem desagradado ao ponto de te levar a fazer quinhentas léguas e a expor-te a naufrágios para deles te afastares. De ninguém poderias esperar um tratamento assim! (ALCOFORADO, 1974, p. 73-75).

Visto que o fluxo do tempo em Cartas Portuguesas é marcado pelo entrecruzamento de eventos presentes com eventos pretéritos, entre os quais o elo é feito pela memória da narradora-protagonista, não só ocorre uma desvalorização da ação, já que o importante é a irrupção dos sentimentos da personagem, como também a configuração do espaço será determinada pela ordenação do tempo. Dessa forma, o espaço diegético, no referido romance, como será filtrado pelo olhar da narradora-personagem, emergirá tripartido em real, íntimo e revisitado, apesar de ele ser representado tomando-se como parâmetro um mesmo referente - o macroespaço do convento dentro do qual se destaca o microespaço do claustro:

[...] este convento, tudo me é insuportável! $[\ldots]$

Dona Brites andou atrás de mim nestes dias para me fazer sair da minha cela, e, julgando divertir-me, levou-me a passear para a varanda donde se avista Mértola. Fui com ela, e logo me assaltou uma 
lembrança cruel que me fez chorar todo o resto do dia. Voltou a trazer-me para dentro, e deitei-me na cama [...]

Vi-te muitas vezes passar neste lugar com um ar que me encantava, e eu estava naquela varanda naquele dia fatal em que comecei a sentir os primeiros efeitos da minha infeliz paixão. [...] convenci-me de que me tinhas notado entre todas as que estavam comigo, e imaginei que, quando passasses, ficarias contente se eu te visse melhor e se admirasse a tua destreza e a boa graça quando montavas o teu cavalo (ALCOFORADO, 1974, p. 65-67).

Além da elaboração do tempo, das modalidades de representação dos diferentes segmentos de informação diegética, da caracterização da instância responsável pela narração, da configuração do espaço e das personagens (REIS; LOPES, 1988), conforme mostrado nos parágrafos anteriores, o estatuto literário das Cartas Portuguesas é assegurado não só pelo manuseio desses signos técnico-narrativos, mas também pela presença das seguintes linhas-mestras:

A desesperação do abandono, a lógica sentimental, de tender para justificar o que se deseja, a voluptuosidade agridoce de gozar no sofrimento, o transporte de absorver toda a personalidade no ente amado, as contradições constantes de quem só toma posições extremas e insustentáveis e se debate num incessante vaivém, como havendo perdido o rumo no pego encapelado do sentimento, todo o delírio imaginoso de uma alma reduzida à imobilidade e à clausura, orgulhosa 
de haver ascendido a um cume excelso donde avistou larga amplidão de ideal, a alternativa de querer ciosamente guardar no coração recordações da perdida felicidade, como tesouro vedado a almas vulgares, para logo fraquejar ante o penoso dessas memórias - todos os extremos doidejantes duma alma rica de emotividade, sem equilíbrio e sentido das realidades, tudo que uma paixão absorvente pode produzir, ali está expresso naquela pequena história dum grande amor. $\mathrm{O}$ martírio do abandono, o inferno de amar já sem esperança e a desolação de quem entrevê toda uma vida de soledade e tristeza trespassam as cartas, não com a monotonia plangente das lamentações, mas em traços rápidos e incisivos, feitos de cobardia egoísta e egoísmo orgulhoso (FIGUEIREDO, 1955, p. 214-215).

Como a leitura que propomos do romance de Sóror Mariana Alcoforado deverá “[...] não descobr[ir] o que a obra contém, em sua verdade essencial, mas literalmente recria[r] a obra, atribuindo-lhe sentido(s)" (PERRONEMOISÉS, 1998, p.13), cremos que poderemos atingir melhor esse objetivo se alocarmos nossa leitura no campo da psicologia, notadamente nas reflexões de Nasio (2007) sobre a dor de amar. Isso porque Cartas Portuguesas fala de uma experiência interior que traz consigo, amalgamados, amor e dor, que compõem as tintas com as quais as cartas foram escritas, relação essa 


\section{4}

que pode ser entrevista já na primeira das cinco cartas que compõem a referida obra:

Uma paixão sobre a qual tinha feito tantos projectos de prazeres não te causa agora mais do que um mortal desespero, só comparável à crueldade da ausência que o provoca. E esta ausência, para a qual a minha dor, por mais que se esforce, não consegue encontrar um nome assaz funesto, hão-de então privar-me para sempre de fitar esses olhos onde eu via tanto amor, esses olhos que me faziam saborear emoções que me cumulavam de alegria, que eram o meu tudo, a tal ponto que deles só precisava para viver? (ALCOFORADO, 1974, p. 13).

Trazendo, à tona, a confissão de um sujeito feminino atordoado pelo amor-paixão, o discurso amoroso urdido na prosa de Mariana Alcoforado pode, a nosso ver, ser relacionado à tradição amorosa portuguesa que remonta ao Trovadorismo, mais especificamente às cantigas de amigo. Como as cantigas desse gênero, as cartas de Mariana contêm a confissão amorosa de uma mulher cuja coita (o sofrer de amor) é haurida do fato de entreter amores com um homem que a abandonou, porque precisava prestar serviço militar para o qual ele, aparentemente, foi forçado a ir. De maneira geral, são esses os aspectos que fazem com que as cartas da freira de Beja mantenham ligação direta com o sofrer de amor que marcou a produção literária portuguesa em seus primórdios e que, enunciado por um sujeito feminino, revela-se um lamento em que se encontram imiscuídas a dor do abandono e a saudade por quem não mais aparecerá. 
Entretanto, se nas cantigas de amor, o discurso amoroso, embora proferido por uma voz feminina, era elaborado por um homem, o trovador; se o amigo, tomado como sinônimo de amado ou amante, havia se distanciado por uma obrigação alheia à sua vontade e à de sua amada, nas Cartas Portuguesas, a situação é outra. Em outras palavras, se nas cantigas são os homens-trovadores que, simpatizando com os interesses femininos, assumem o ponto de vista feminino para falar de coisas femininas; nas Cartas Portuguesas, deixando de lado as rusgas com relação à autoria, podemos dizer que elas não só enunciam um discurso feminino, no que tange ao sofrer de amor, como também foram escritas por uma mulher que se assume como sujeito de um discurso amoroso que instaura uma dicção feminina na literatura portuguesa, retomada, por exemplo, anos mais tarde, por uma poetisa do porte de Florbela Espanca. Se o feminino, no período em que Cartas Portuguesas surge, época eminentemente masculina, era sempre o oculto; com Mariana Alcoforado, ele emerge, tornando-se o centro de enunciação de uma voz feminina, ainda que irrompa de um lugar de aprisionamento - o convento:

Se me fosse possível sair deste malfadado claustro, não esperaria em Portugal que se cumprissem as tuas promessas: iria eu, sem qualquer inibição, procurar-te, seguir-te e amar-te por toda a parte. Não ouso iludir-me de que isso possa acontecer e não quero alimentar uma esperança que me daria, é certo, algum prazer. Agora já só desejo ser sensível às minhas dores (ALCOFORADO, 1974, p. 19). 


\section{6}

Prosseguindo com a analogia com as cantigas de amigo, ao contrário destas, a ausência do amado, em Cartas Portuguesas, foi escolhida por ele próprio e não à sua revelia, como podemos perceber no trecho em destaque no seguinte excerto, embora não possamos descurar do fato de que quem manipula a cena da enunciação é a signatária das cartas e que os fatos são narrados a partir de um único ponto de vista - o dela:

Ai de mim! Os meus [olhos] encontram-se privados da única luz que os animava e só lhes restam as lágrimas; não os tenho usado senão para chorar incessantemente, desde que soube que estavas decidido a um afastamento que não posso suportar e me fará morrer em pouco tempo (ALCOFORADO, 1974, p. 13, itálicos nossos).

O trecho estavas decidido a um afastamento sinaliza, textualmente, a verdadeira hipótese de a ausência do amado, narratário das cartas, que atendia pelo nome de Sr. de Chamilly, ter sido uma escolha sem coação alguma, ainda que se lhe atribua como causa a necessidade de retornar à França, país de sua origem. Enfim, na visão daquela que subscreve as cartas, a causa da ausência do amado foi mesmo o abandono voluntário:

Mil vezes ao dia dirijo para ti os meus suspiros: eles procuram-te em toda a parte e, como recompensa de tantas inquietações, apenas me trazem o aviso demasiado sincero da minha triste sorte, que tem a crueldade de não suportar que 
eu me iluda e que a cada passo me diz: basta!, basta!, infeliz Mariana, basta de te consumires em vão e de procurares um amante que nunca mais voltarás a ver; um amante que atravessou o mar para fugir de ti, que está em França no meio de prazeres e nem por um momento pensa nas tuas dores; um amante que te dispensa de todos esses transportes que nem sequer te agradece (ALCOFORADO, 1974, p. 15, itálicos nossos).

Todavia, embora dialogue com a tradição amorosa portuguesa que alude à época do Trovadorismo, Mariana Alcoforado, em suas cartas, fala do amor, acrescentando-lhe novas nuanças, de forma que, no dizer de Figueiredo (1974, p. 104), o que "ressalta das páginas ardentes em que a pobre freira abandonada vaza os segredos do seu coração" é um amor diferente no qual é possível, para muitos, "entrever a caracterização da alma do povo que lhe deu origem":

Trata-se, com efeito, de um amor com acentos novos, o amor da dedicação total, o amor em que a totalidade do ser se encontra emprenhada, o amor extremo em que o pensamento do "outro" é o valor a que se reportam e se subordinam todas as opções, o amor em que o eu praticamente se aniquila, encontrando a sua subsistência apenas no dar-se, no estar para. (FIGUEIREDO, 1974, p. 104-105).

Cremos que, dentre os matizes novos que podem ser desentranhados do discurso amoroso das Cartas Portuguesas, está um sentimento tipicamente português: a 


\section{8}

saudade, a qual diz muito da maneira portuguesa de amar, de estar no mundo e de encarar a vida (FIGUEIREDO, 1974). Por saudade, que vem do latim solus, solitas, solitatis e da qual também vêm sozinho, solidão, devemos entender, na esteira de Gaudêncio (2007), a dobra entre o que foi e o que fica do que já não mais é, a conversão daquilo que se nos afigura insuportável em algo que dá sentido à nossa existência, a presentificação de ausências, hiância a adiar preenchimentos, faltas de que e para as quais somos feitos, pedaços de uma alma em frangalhos ante o outro que está, irremediavelmente, perdido. Da saudade, afirmou D. Francisco de Mello:

É a saudade uma mimosa paixão da alma, e por isso tão subtil, que equivocadamente se experimenta, deixando-nos indistinta a dor da satisfação. É um mal, de que gosta, e um bem que se padece: quando fenece, troca-se a outro maior contentamento, mas não que formalmente se extinga: porque se sem melhoria se acaba a saudade, é certo que o amor e o desejo se acabarão primeiro. (MELLO apud LOURENÇO, 1999, p. 29).

É, portanto, a saudade a chama que mantém aceso o amor-paixão de Sóror Mariana Alcoforado e que lhe alimenta os sentidos, a razão de ser e de existir. No dizer de Fidelino de Figueiredo, "a paixão deu ao natural talento [de Mariana] o dom excepcional de expressar com relevo e emoção cálida o mundo revolto de sua alma" (FIGUEIREDO, 1955, p.214). Por isso, do começo ao fim, uma única 
isotopia permeia as cinco cartas: o convalescer por amor. As cartas são, portanto, a materialização/eternização do amor-paixão de Mariana e do seu desespero advindo da distância que a separa, física e emocionalmente, do seu amado, tanto que ela chega a confessar: "Eu escrevo mais para mim do que para ti, e aquilo que procuro é consolar-me" (ALCOFORADO, 1974, p. 75).

Como tal, as cartas mostram as contradições desse sujeito ébrio de amor que, ao mesmo tempo em que acusa o ser amado, quando questiona "Por que é que puseste tanto empenho em me tornar infeliz? Por que não me deixaste em paz no meu convento? Tinha-te feito algum mal?" (ALCOFORADO, 1974, p. 19), também lhe pede perdão: "Perdoa-me! Eu não te culpo de nada! Não estou em condições de pensar na minha vingança e só acuso a dureza de minha sorte" (ALCOFORADO, 1974, p. 19). Enfim, um sujeito que, diante da perda do objeto de desejo, inicia um trajeto permeado pela negação ("De ti não quero nada senão o que espontaneamente vier e recuso todos os testemunhos de amor que constrangido me desses"), pela raiva ("Deixa de encher as tuas cartas com coisas inúteis e nunca mais escrevas a dizer que me lembre de ti"), pela barganha ("Prometo-lhe não o odiar; por de mais desconfio dos sentimentos violentos para me atrever a fazê-lo"), pela depressão ("As minhas dores já não podem ter consolo e a lembrança das alegrias passadas enche-me de desespero") e pela resignação ("Resisto a todas as evidências que me deviam persuadir de que já não me amas e sinto-me muito mais disposta a abandonar-me cegamente à minha paixão do que aos motivos que me dás para queixar-me da tua falta de atenção"). 
Como o ser amado, apesar de amado, é também a fonte de onde emanam nossas angústias, medos e incertezas, escrever revela-se para Mariana a única forma de tornar presente o que se fizera ausente: "Parece-me que estou a te falar quando te escrevo e que tu me estás um pouco mais presente" (ALCOFORADO, 1974, p. 73). Por meio das cartas, ela tenta substituir uma perda, recriando, então, a imagem daquele por quem anseia, espera, chora, sofre. Além disso, as cartas servem como prolongamento de um amor que passou a existir apenas como lembrança, ausência, falta, espaço lacunoso, vacância, daí a tentativa de preenchê-lo através da escrita, o que torna, no dizer da narradora, mais veemente o amor sentido e mais plena a vida dela:

Lamento, só por amor de ti, os prazeres infinitos que perdeste: será que os não tenhas querido gozar? Ah! Se os conhecesses, verias que eles são mais intensos do que o de me teres seduzido, e terias experimentado que se é muito mais feliz e que se sente algo de bem mais tocante quando se ama com violência do que quando se é amado! (ALCOFORADO, 1974, p. 29).

Neste caso, em Cartas Portuguesas, am(a)or conjuga-se como do(e)r: "Adeus! Não posso mais! Adeus! Ama-me sempre e faze-me sofrer ainda maiores males" (ALCOFORADO, 1974, p. 21). Dessa forma, à medida que um aumenta (o amor ou a dor), o outro também o faz em igual proporção: "Porque me fez conhecer a imperfeição e o desencanto dum afecto que não deve durar eternamente e as dores que acompanham um amor violento, quando ele 
não é recíproco" (ALCOFORADO, 1974, p. 89). O sofrimento por que passa Mariana Alcoforado advém da tentativa vã de não se desprender do seu objeto de desejo: "A minha religião e a minha honra, faço-as consistir unicamente em te amar loucamente por toda a minha vida, já que a amar-te comecei!" (ALCOFORADO, 1974, p. 33). Como a narradora-personagem não consegue instaurar em seu inconsciente outro objeto de desejo, aquele que fora o antigo mantém-se ainda no campo de projeção dela, como uma imagem que não quer apagar:

Resisto a todas as evidências que me deviam persuadir de que não me amas e sinto-me muito mais disposta a abandonar-me cegamente à minha paixão do que aos motivos que me dás para me queixar da tua falta de atenção. (ALCOFORADO, 1974, p. 57).

Por agir renitentemente e insistir em ter aquilo que só pode ser tido como perda, é que o inconsciente da narradora-personagem é marcado pela impossibilidade de instauração da coexistência do antigo amor com um possível novo amor:

Bem claramente vejo qual seria o remédio para todos os meus males e em breve me libertaria deles se deixasse de te amar. Mas, ai de mim!, que terrível remédio! Não! Antes quero sofrer ainda mais do que esquecer-te... Infeliz que sou! Dependerá isso de mim? Não posso acusar-me de ter desejado, nem que fosse só por um momento, deixar de te amar! (ALCOFORADO, 1974, p. 29). 
Por ainda não se desprender do antigo amor, a freira de Beja não consegue para si um novo eleito, propiciando que irrompa a dor, a expressão lancinante de quem insiste em reconhecer que sofre por aquilo que não é mais seu ou que mesmo nunca foi:

Estou convencida de que talvez venha a encontrar nesta terra um amante mais fiel e melhor. Mas, ai de mim!, quem poderá despertar em mim o amor? Bastará a paixão de um outro homem para me encher? Teve a minha sobre si algum poder? Não experimentei eu que um coração enternecido jamais esquece aquilo que o fez conhecer transportes que não conhecia e de que era capaz?; que todas as suas emoções estão ligadas à aquele que idolatrou?; que os seus primeiros sonhos e as suas primeiras feridas não podem ser nem curadas nem apagadas?; que todas as paixões possam vir em seu auxílio e que se esforçam por o encher e contentar lhe prometem em vão um sentimento que nunca mais encontra?; que todos os prazeres que procura, sem qualquer vontade de os encontrar, só servem para bem lhe fazer conhecer que nada lhe é tão caro como a lembrança das suas dores? (ALCOFORADO, 1974, p. 89).

Em um processo em que é reiteradamente curtida e acalentada a dor advinda de um amor que não é recíproco, Mariana Alcoforado sofre, sem que tenha sequer alguém que lhe acolha a sua dor. Por isso, advém a necessidade narcísica de escrever essa dor, de fazer da escrita uma espécie 
de extensão da dor causada pelo (des)amor, o que, de certa forma, desperta prazer nesse sujeito que se compraz muito mais no exercício da dor, do que no exercício de amar:

Eu não sei nem o que sou, nem o que faço, nem o que desejo: encontro-me dilacerada por mil movimentos contrários. Poder-se-á imaginar estado tão deplorável?

[...]

O meu desespero estará então apenas nas minhas cartas? Se te amasses tanto como mil vezes tenho dito, não teria já morrido há muito tempo?

[...]

Adeus! Parece-me que falo de mais no estado deplorável em que me encontro. No entanto, do fundo do coração te agradeço o desespero que me causas, e detesto a tranqüilidade em que vivi antes de te conhecer (ALCOFORADO, 1974, p. 45-51).

A dor é a prova por que temos de passar quando somos compelidos a enfrentar "[...] a separação de um objeto que, deixando-nos súbita e definitivamente, nos transtorna e nos obriga a reconstruir-nos" (NASIO, 2007, p. 20), daí por que mais difícil do que a dor da separação é aperceber-se da necessidade de reconstrução diante de uma perda que se nos afigura inassimilável:

Só conheci bem o excesso do meu amor quando quis fazer todos os esforços para me curar dele, e receio que não tivesse ousado aventurar-me a essa empresa se tivesse podido prever-lhe todas as dificuldades e violências. Estou 
convencida de que teria experimentado sensações menos desagradáveis amando-o, ingrato, embora, como é, do que deixando-o para sempre. Tive então a prova de que lhe quero menos do que à minha paixão, e suportei dores indescritíveis em a combater, depois que a infâmia da sua maneira de proceder o tornaram odioso aos meus olhos. (ALCOFORADO, 1974, p. 83).

No excerto acima, além do reconhecimento da dificuldade inerente à reconstrução psíquica após uma perda, devemos destacar que, para a enunciadora, mais do que a pessoa do ser amado, ganha relevância o fato de poder amar. Neste caso, as dores que sentia Mariana eram acalentadas não porque ela tivesse alguém a quem amar, mas porque ela simplesmente amava. Sendo assim, mais importante do que ter um objeto de desejo, é poder sentir-se um sujeito desejante, isto é, não um sujeito que desperta desejos, mas um sujeito que é capaz de desejar, de amar o amor e não os amores. De certa forma, essa é uma postura que procura buscar uma compensação no fato de sentir dor, isto é, conformar-se com a dor inerente ao exercício de amar.

Em Cartas Portuguesas, em uma leitura ligeira, poderíamos afirmar que a narradora-protagonista passa pelo processo de elaboração do luto em virtude da perda do amado, evento esse que ela não quer ver como perda, daí a insistência em continuar tendo aquilo que já não mais existe, em manter-se presa a uma espécie de fantasma. Como mola propulsora que nos impele ao crescimento psíquico, a dor advém não apenas da perda do ser amado, mas pode advir também do abandono, da humilhação ou da mutilação. Entretanto, 
todas essas formas em que se configura a dor estão sedimentadas em uma mesma base: "a amputação brutal de um objeto amado, ao qual estávamos tão intensa e permanentemente ligados que ele regulava a harmonia de nosso psiquismo" (NASIO, 2007, p. 21). Como o objeto que a protagonista da obra em tela perdeu foi o amor, ou, pelo menos, aquilo que ela projetou como o sendo, podemos dizer que a dor dela "só existe sobre um fundo de amor" (NASIO, 2007, p.21).

De acordo com Nasio (2007), uma das formas de ver a dor psíquica é tomá-la como dor de amar. Por isso, ela é o afeto derradeiro, é um limiar entre a loucura e a morte, mas, mesmo assim, não se morre dessa dor, porque, "enquanto há dor, também temos as forças disponíveis para combatê-la e continuar a viver" (NASIO, 2007, p. 23), ainda que o sujeito acometido da dor de amar não a perceba dessa maneira, mas, sim, como o fim de tudo, como o prenúncio da morte. Ele a sente, dessa forma, por causa do fato de que a dor psíquica só existe porque perdemos aquele objeto para o qual investimos nossa energia psíquica. No entanto, "o que dói não é perder o ser amado, mas continuar a amá-lo mais do que nunca, mesmo sabendo-o irremediavelmente perdido" (NASIO, 2007, p. 41). Desse modo, a perda súbita do amado ou do amor dele é que provoca o rompimento do laço amoroso e faz o eu emergir em desespero, em dor, em um processo em que se vê compelido a debater-se consigo próprio:

Não tendo, em última análise, de combater senão contra mim própria, não podia imaginar toda a minha fraqueza, nem compreender tudo o que agora sofro. 
Enfureço-me contra mim própria quando penso em tudo quanto te sacrifiquei: perdi a minha reputação, expus-me ao furor dos meus parentes, à severidade das leis deste país contra as religiosas e à tua ingratidão, que me parece a maior de todas as desgraças. (ALCOFORADO, 1974, p. 42-45).

Em Cartas portuguesas, é a separação do amado, aliada à indiferença dele, que desencadeia a dor na protagonista, de modo que o seu amar e o seu sofrer estão de tal forma imiscuídos que, como já dissemos, a intensidade de um cresce na mesma proporção que a do outro. Sendo assim, ao contrário do que comumente pensamos, isto é, que o amor nos serve como lenitivo e proteção contra a dor, o sofrimento amoroso de que é acometida Mariana Alcoforado demonstra que o amor é, de fato, o centro de onde emana a dor. Aliás, como, paradoxalmente, já constatara Freud, "nunca estamos tão mal protegidos contra o sofrimento como quando amamos, nunca estamos tão irremediavelmente infelizes como quando perdemos a pessoa amada ou o seu amor" (apud NASIO, 2007, p. 34). Isso ocorre porque a dor de amar, espécie de dilaceramento da alma, é uma dor traumática advinda da ruptura do laço que nos liga àquele que elegemos como centro de nosso desejo, provocando o desordenamento de nossas tensões pulsionais e tornando inoperante o princípio do prazer ao qual escapam as variações extremas de tensão inconsciente. No entanto, ao mesmo tempo em que é desencadeada por uma perda, a dor é também uma reação contra o desaparecimento do ser 
amado, conforme podemos depreender a partir do seguinte excerto em que a narradora confessa:

Adeus! Bem gostaria de nunca ter te visto! Ah! Como sinto a falsidade deste sentimento e vejo, neste preciso momento em que te escrevo, que gosto bem mais de ser desgraçada amando-te do que gostaria de nunca te ter visto! Aceito, pois, sem lamentações a minha triste sorte, já que tu a não quiseste tornar melhor. (ALCOFORADO, 1974, p. 49).

Ao se obstinar em querer compensar a ausência real do outro perdido intensificando a imagem dele, o eu da protagonista está tentando manter presente aquilo/aquele que, consoante já foi apontado, só poderá existir apenas como uma ausência, uma falta, uma lacuna, um espaço vazio em busca de um preenchimento sempre adiável, o que desencadeia um processo em que "o eu desinveste subitamente a quase totalidade de suas representações para superinvestir maciçamente numa única representação, a representação do amado que não mais existe" (NASIO, 2007, p. 39). Consequentemente, o sujeito que sofre se vê obrigado a justificar a recusa daquele que lhe é o centro do seu sofrer: "No entanto, o amor que tenho por ti serve-te com tanta fidelidade que não posso consentir em te considerar culpado senão para gozar do inefável prazer de eu próprio te justificar" (ALCOFORADO, 1974, p. 59).

Nesse sentido, devido ao fato de a narradora-personagem sofrer pela perda de um objeto querido, seríamos levados a pensar que ela entra em estado de luto. Entretanto, 
como uma reação a uma perda afetiva, a dor psíquica difere-se do luto. Se nela há uma espécie de reação defensiva do eu, com o superinvestimento da representação do objeto perdido; no luto, temos o movimento contrário: há um desinvestimento progressivo em torno da representação do objeto perdido, isto é, há uma redistribuição da energia psíquica que fora concentrada na representação do ente e/ou objeto amado perdido (NASIO, 2007).

Sendo assim, em Cartas Portuguesas, é mais apropriado falarmos de dor psíquica do que, propriamente, de luto, ainda que este seja um dos componentes relacionados à irrupção da dor psíquica. Mesmo diante da perda do objeto querido, o eu da protagonista-narradora não consegue desencadear o processo de desinvestimento da energia psíquica, uma vez que "era-me demasiado agradável sentir que estava contigo para poder pensar que um dia te afastarias de mim" (ALCOFORADO, 1974, p. 29). Por sua vez, ela não dá início ao processo de elaboração do luto, fazendo com que o langor e o amor confluam para alimentar a dor em seu mais puro estado: a dor psíquica, processo esse que poderá gerar um luto patológico, estado crônico em que se encontram sujeitos, como a narradora-protagonista de Cartas Portuguesas, que insistem em alimentar a onipresença psíquica do objeto de desejo perdido:

E, no entanto, não me arrependo de te haver adorado e sinto-me bem mais feliz por me teres seduzido! A tua ausência rigorosa, e talvez eterna, em nada diminui a veemência do meu amor. Quero que todos o saibam, e disso não faço mistério, que estou encantada por ter 
feito por ti tudo quanto fiz contra toda a espécie de decoro. A minha religião e a minha honra, faço-as consistir unicamente em te amar loucamente por toda a minha vida, já que a amar-te comecei! (ALCOFORADO, 1974, p. 33.)

Como a narradora-protagonista da obra em análise insiste no superinvestimento da figura do objeto perdido, o eu dela nega-se a reconhecer a perda do objeto de desejo, reação essa que, conforme já dito, caracteriza mais o exercício da dor de amar do que o exercício de elaboração do luto. De acordo com Nasio (2007), a insistência na representação do objeto de desejo perdido é a maneira encontrada pelo eu para reagir diante da perda desse objeto. Por isso, o eu investe todas as suas forças para manter viva a imagem do objeto desaparecido, desencadeando um processo mental marcado pelo desinvestimento e pelo superinvestimento de sua energia psíquica, o que ocasiona, ao mesmo tempo, o esvaziamento súbito do eu e a concentração de energia na representação do amado desaparecido, gerando, por conseguinte, a dor psíquica. Esta, por sua vez, provoca a cisão do eu em duas partes: uma em que o eu ainda está atrelado ao "amor desmedido pela efígie do objeto perdido"; a outra em que o eu, de forma lúcida, constata "a ausência definitiva desse objeto" (NASIO, 2007, p. 42). Essa polaridade que caracteriza a cisão do eu provocada pela dor de amar pode ser, a nosso ver, exemplificada com este excerto do romance em comento, quando a signatária das cartas aventa a seguinte hipótese em relação ao seu amado: "se pudesse ter a certeza de que me tinhas, efetivamente, esquecido" (ALCOFORADO, 1974 p. 41), em que há a dúvida quanto 
à existência, de fato, do esquecimento, por parte do ser amado, mas, ao mesmo tempo, há também o desejo de que esse esquecimento não tenha se instaurado efetivamente. Conforme podemos perceber, a protagonista-narradora obstina-se a manter-se agarrada às imagens onipresentes do amado perdido, afirmando, piedosamente:

Quero, no entanto, que saiba que, de há alguns dias a esta parte, sinto vontade de queimar e destruir estes testemunhos [um retrato e umas pulseiras] do seu amor que me eram tão caros; mas mostrei-me tão fraca para consigo que nunca acreditaria que eu pudesse ser capaz de tais extremos. Desejo, pois, gozar de toda a dor que tive ao separar-me deles e causar-lhe também a si algum despeito. (ALCOFORADO, 1974, p. 81).

O discurso instaurado pela enunciadora de Cartas Portuguesas é um discurso de um sujeito sofredor, exangue e suspenso à lembrança muito viva do amado desaparecido. Enfim, é o discurso de um sujeito marcado pela dor extrema de ver-se sem aquele que era o centro de suas projeções amorosas, daí o estado de Mariana Alcoforado ser um misto de esvaziamento do eu e contração em uma imagem-lembrança: a do ser amado que a abandonou. A dor advinda da perda de um objeto querido é, no dizer de Nasio (2007), a expressão de uma defesa, de um estremecimento de vida, para que aquele que sofre não sucumba de vez e naufrague no nada. Diante do impacto ocasionado por tamanha perda, o sujeito pode ser levado às vascas 
da loucura: "São sempre extremas as emoções que de ti me vêm! Amei-o como louca! $O$ desprezo que eu tive por todas as coisas!" (ALCOFORADO, 1974, p. 59; 93). Esse estado é decorrente do fato de o sujeito, em vez de dissipar o seu sofrimento, concentrá-lo, porque insta em não relegar para o esquecimento aquele/aquilo que continua sendo objeto de desejo ("Adeus! A minha paixão aumenta a cada momento! Ah!, quantas coisas tinha ainda para te dizer!... (ALCOFORADO, 1974, p. 51)), mas um objeto de desejo que, no presente, só existe, irremediavelmente, como faltoso, faltante, em falta.

O sujeito que sofre até percebe o seu objeto de desejo como faltoso, mas recusa-se a aceitá-lo como tal, gerando, assim, um desequilíbrio que só será resolvido quando, no inconsciente do sujeito, estiver sido instaurada a coexistência entre o antigo e o novo objeto de desejo. Por isso, a imagem do ser desaparecido não deve ser apagada, uma vez que ela é imprescindível no processo de restauração do equilíbrio psíquico. O problema está no fato de essa imagem tornar-se uma onipresença psíquica, desencadeando, dessa forma, um luto patológico, como parece ser o caso em que se encontra a narradora-protagonista de Cartas Portuguesas para quem a imagem do ser amado persiste como uma sombra que não pode ser esgarçada. Por outro lado, caso a instauração do luto patológico não venha a acontecer, a imagem do desaparecido poderá conviver com a imagem do novo eleito, já que esta não implica na substituição daquela. Todavia, o mais difícil de ser percebido pelo sujeito enlutado é o fato de que ele precisa direcionar a sua energia psíquica para outro objeto de desejo, isto é, investir em outro a energia que foi saturada no antigo ser e/ou 
objeto de desejo. Por isso, a dor mental é um componente importante no processo de crescimento psíquico, já que o seu telos não é provocar o dilaceramento do sujeito, mas a necessidade de reconstrução diante da desarmonização do psiquismo provocada pela perda objetal.

O nosso sistema psíquico é regido pela díade desprazer/prazer e marcado pela tentativa de descarregar a tensão gerada pelo desprazer (estado de tensão) e pelo prazer (descarga parcial de tensão). A polaridade entre prazer e desprazer parece configurar a estrutura do desejo, este que é "uma tensão ardente vista em movimento, orientada para um alvo ideal, o de chegar ao prazer absoluto, isto é, à descarga total" (NASIO, 2007, p. 48). Nesse sentido, se o ser humano se define como um ser de desejo, ser humano é ser marcado pela insatisfação de um desejo, o que parece definir-se como condição sine qua non da vida, mola que a faz mover-se. Sendo humanos, somos marcados, inapelavelmente, mais pelas necessidades de carências do que pelo preenchimento delas, ainda que seja esse, a priori, o que pensamos buscar. Como polo organizador do desejo, a carência é o núcleo atraente sem o qual "o impulso circular do desejo se perturbaria e então só haveria dor" (NASIO, 2007 , p. 49). No caso do romance aqui em análise, a insatisfação que acomete a narradora-protagonista é demasiado penosa, fazendo com que o desejo perca o eixo e, da turbulência das pulsões decorrentes da desestabilização do seu sistema psíquico, possa a dor emergir como sintoma dos efeitos provados no inconsciente da personagem-narradora pela ausência do ser amado. 
Se a carência é essencial para a manutenção de nossa consistência psíquica, ela é mantida no nível do suportável graças à presença do outro como esfera que organiza nosso desejo. Nosso eleito assume, portanto, um papel restritivo cujo objetivo é assegurar "a consistência psíquica pela insatisfação que ele faz nascer, e não pela satisfação que ele proporciona" (NASIO, 2007, p. 50). Relacionando isso ao romance em comento, podemos afirmar que, como objeto de desejo de Mariana Alcoforado, Chamilly foi capaz de excitar o desejo dela, mas não o pôde satisfazer plenamente. A ela, ele proporcionou um gozo parcial, de forma que, do ponto de vista psicológico, ela sentiu-se insatisfeita. Só depois da perda é que podemos perceber o quanto ele, como objeto capaz de recentrar psicologicamente o desejo de Mariana, estava enraizado no inconsciente dela.

Em Cartas Portuguesas, registro doloroso dos efeitos provocados pela ausência do ser amado, a dor de Mariana Alcoforado é, portanto, a dor do caos das pulsões descontroladas, ocasionado pela ruptura do laço entre aquele que ama e seu objeto amado, daí por que a dor de amar nesse romance é decorrente da "autopercepção que [o eu da narradora-protagonista] tem do tumulto interno desencadeado por essa perda", ou seja, a dor que sente a narradora-personagem e que alimenta todas as suas cartas é haurida do "encontro brutal e imediato entre o sujeito e o seu próprio desejo enlouquecido" (NASIO, 2007, p. 27; 72). Em virtude disso, o discurso amoroso engendrado por Mariana Alcoforado parece reiterar ao seu amado um único enunciado: "fazes-me falta", como se, assim, ela pudesse manter vivo o ritmo que lhe alimentava o impulso desejante e que emanava da imagem fantasiada do outro, o eleito, esse 
personagem psíquico que criamos, que nos é insubstituível e que, na mesma proporção que nos satisfaz, também nos insatisfaz. Na tentativa de preencher a ausência incontestável do amado, Mariana Alcoforado, o ser que sofre, procura dizer a dor que sente ante a falta do amado, escrevendo-a, fazendo-a tornar-se carne por meio do verbo, ou melhor, fazendo do verbo a expressão de uma dor lancinante com a qual a narradora, na senda entre a carne e a alma, aprendeu a conviver mediante o doloroso exercício da dor de amar.

\section{Referências}

AGUIAR e SILVA, Vitor Manuel de. O romance. In: . Teoria da Literatura. 3. ed. Coimbra:

Almedina, 1979.

ALCOFORADO, Sóror Mariana. Cartas Portuguesas. Publicações Europa América, nº. 90, 1974.

FIGUEIREDO, Fidelino de. Literatura Portuguesa. Rio de Janeiro: Livraria Acadêmica, 1955.

FIGUEIREDO, Nuno de. Breve nota sobre as Cartas Portuguesas. In: ALCOFORADO, Sóror Mariana. Cartas Portuguesas. Publicações Europa América, nº.90, 1974.

GAUDÊNCIO, Edmundo de Oliveira. Cartografia da saudade: apontamentos para a clínica do luto. In: RIBEIRO, Maria Goretti.; SILVEIRA, Maria de Fátima de Araújo.; OLIVEIRA, José Alex Nogueira de (Orgs.). Corpo e 
alma: terapias biopsicossociais. João Pessoa: Editora Universitária/UFPB, 2007, p. 67-76.

LOURENÇO, Eduardo. Mitologia da saudade: seguido de Portugal como destino. São Paulo: Companhia das Letras, 1999.

NASIO, Juan-David. A dor de amar. Tradução de André Telles e Lucy Magalhães. Rio de Janeiro: Jorge Zahar, 2007.

PAIXÃO, Sylvia. Introdução. In: ALMEIDA, Júlia Lopes de. Correio da roça. Rio de Janeiro: Instituto Nacional do Livro, 1987.

PERRONE-MOISÉS, Leyla. Altas literaturas: escolha e valor na obra crítica de escritores modernos. São Paulo: Companhia das Letras, 1998.

REIS, Carlos.; LOPES, Ana Cristina M. Dicionário de teoria literária. Petrópolis: Vozes, 1988.

VALENTIM, Claudia Atanazio. O romance epistolar na literatura portuguesa da segunda metade do século XX. Rio de Janeiro, 2006. Tese (Doutorado em Literatura Portuguesa), Faculdade de Letras, Universidade Federal do Rio de Janeiro, 2006. 